\title{
INTEGRASI METODE PERBANDINGAN EKSPONENSIAL (MPE) DAN METODE SIMPLE ADDITIVE WEIGHTING (SAW) PADA SISTEM PENDUKUNG KEPUTUSAN PENERIMAAN BEASISWA BERPRESTASI
}

\author{
Octaviana Anugrah Ade Purnama ${ }^{1}$, Sudarno Wiharjo ${ }^{2}$, Yan Mitha Djaksana ${ }^{3}$ \\ ${ }^{1,2}$ Program Studi Teknik Informatika, Pascasarjana Magister Komputer, Sekolah Tinggi Manajemen Informatika dan \\ Komputer Eresha \\ ${ }^{3}$ Program Studi Teknik Informatika, Universitas Pamulang \\ Jl. Raya Puspiptek, Buaran, Kec. Pamulang, Kota Tangerang Selatan, Banten, Indonesia, 15310 \\ 1octavianaanugrah@gmail.com \\ ${ }^{3}$ dosen01994@unpam.ac.id
}

\begin{abstract}
Abstrak - Dewasa ini, perkembangan teknologi sudah sangatlah pesat dimana salah satunya adalah sistem informasi berbasis web yang sudah banyak dimanfaatkan oleh instansi-instansi sebagai sarana pendukung operasional manajemen. Pemanfaatan teknologi informasi tersebut juga sudah mulai digunakan oleh lembaga pendidikan untuk administrasi, promosi, informasi dan lainnya. SMK Wiyata Mandala Bogor merupakan salah satu lembaga pendidikan yang mulai menggunakan teknologi tersebut, dimana beberapa sistem administrasinya sudah menggunakan teknologi berbasis dekstop. SMK Wiyata Mandala Bogor ini berada satu Yayasan dengan SMP Wiyata Mandala Bogor, yang mana apabila peserta didik yang ingin melanjutkan di SMK Wiyata Mandala Bogor akan mendapatkan beasiswa berdasarkan prestasi peserta didik tersebut selama di SMP Wiyata Mandala Bogor sesuai kouta yang disediakan. Sehingga memerlukan sebuah sistem pendukung keputusan yang dapat membantu manajemen pendaftaran dalam memberikan beasiswa. Pendukung keputusan Metode Perbandingan Eksponensial (MPE) dan Simple Additive Weighting (SAW) dipilih karena dalam perhitungannya bisa menggunakan pangkat eksponensial berdasarkan tingkat kepentingan mata pelajaran yang kemudian akan dikalkulasikan berdasarkan bobot tingkat kelas yang sudah ditentukan. Dengan menggunakan Metode Perbandingan Eksponensial (MPE) dan Simple Additive Weighting (SAW) dapat menghasilkan rangking peserta didik terbaik yang akan menerima beasiswa di SMK Wiyata Mandala Bogor.
\end{abstract}

Kata kunci : Sistem Informasi, Beasiswa, Sistem Pendukung Keputusan, Metode Perbandingan Eksponensial (MPE), Simple Additive Weighting (SAW).

\section{Pendahuluan}

\section{A. Latar belakang}

Yayasan Pradnya Paramarta memiliki program beasiswa untuk para alumni SMP Wiyata Mandala Bogor yang ingin melanjutkan ke jenjang SMK dengan memilih SMK Wiyata Mandala Bogor sebagai tempat untuk melanjutkan pendidikan ke jenjang yang lebih tinggi. Hal tersebut membuat para peserta didik SMP Wiyata Mandala Bogor berlomba-lomba untuk mendapatkan beasiswa tersebut. Namun dalam proses pemberian beasiswa tersebut, peserta didik yang daftar ke jenjang SMK terlebih dahulu yang akan mendapat beasiswa, sehingga peserta didik yang benar-benar berprestasi bisa menjadi besar kemungkinan tidak mendapatkan beasiswa tersebut.

Metode Perbandingan Eksponensial (MPE) adalah salah satu metode dari Sistem Pendukung Keputusan (SPK) yang digunakan untuk menentukan urutan prioritas alternatif keputusan dengan multi kriteria. Metode Perbandingan Eksponensial (MPE) mampu untuk menentukan urutan prioritas alternatif keputusan dengan menggunakan beberapa kriteria. Metode Perbandingan Eksponensial (MPE) merupakan salah satu metode pengambilan keputusan yang mengkuantifikasikan pendapat seseorang atau lebih dalam skala tertentu. Pada prinsipnya Metode Perbandingan Eksponensial (MPE) merupakan skoring terhadap pilihan yang ada. Adapun kriteria yang digunakan adalah nilai-nilai 
mata pelajaran inti standard Ujian Nasional SMP seperti Bahasa Indonesia, Bahasa Inggris, Matematika serta mata pelajaran pendukung lainnya yaitu Ilmu Pengetahuan Sosial (IPS) serta Teknologi Informasi dan Komunikasi serta kriteria-kriteria non pendidikan formal selama peserta didik tersebut menempuh pendidikan di SMP WIyata Mandala Bogor.

Sedangkan Simple Additive Weighting $(S A W)$ adalah salah satu metode pendukung yang dikenal sebagaia algoritma dengan penjumlahan berbobot. Metode ini membutuhkan proses normalisasi matriks keputusan ke suatu skala yang dapat dengan semua rating dari alternatif yang tersedia. Skor total untuk alternatif diperoleh dengan menjumlahkan seluruh hasil perkalian antara rating (yang dapat dibandingkan lintas atribut) dan bobot tiap atribut. Kriteria yang diterapkan dalam penelitian ini adalah tingkat kelas mulai dari kelas VII, VIII dan IX dengan tingkat kepentingan semester yang berbedabeda.

\section{B. Tinjaun Pustaka}

Pemberian beasiswa merupakan program kerja yang ada di setiap sekolah. Program beasiswa diadakan untuk meringankan beban siswa dalam menempuh masa studi khususnya dalam masalah biaya. Pemberian beasiswa kepada siswa dilakukan secara selektif sesuai dengan jenis beasiswa yang diadakan, penerima beasiswa berprestasi dalam lingkup peserta akademik, nilai rata-rata raport terakhir, absensi kehadiran, berprilaku baik, berakhlak baik, aktif dalam organisasi. Pemberian Beasiswa merupakan penghasilan bagi yang menerima dan tujuan beasiswa adalah untuk membantu meringankan beban biaya pendidikan siswa yang mendapatkan beasiswa. Dalam perhitungan penulis menggunakan metode Simple Additive Weighting (SAW), karena metode ini cocok digunakan untuk perhitungan yang akurat dan sangat membantu dalam perhitungan setiap data yang diperoleh (Hidayat, 2017).

Seorang kepala Madrasah yang berkualitas, akan memberikan kinerja terbaik di Madrasah yang dipimpinya, sehingga tercipta generasi yang pandai, berbudi pekerti yang luhur serta beragama yang baik. Kementrian Agama Republik Indonesia yang berkantor di Kota Mataram berupaya menjaga dan meningkatkan kualitas kepala Madrasah agar Kepala Madrasah yang berada di kota Mataram memiliki motivasi untuk terus meningkatkan kualitas dirinya. Perancangan dan pembuatan sistem dalam penelitian ini menggunakan metodologi waterfall dan menggunakan Metode Perbandingan Eksponensial (MPE) yang merupakan salah satu metode dari Sistem Pendukung Keputusan (SPK). Metode MPE ini digunakan untuk menentukan prioritas alternatif keputusan dengan multi kriteria. Hasil dari penelitian ini berupa tabel penilaian peringkat kepala Madrasah terbaik di kota Mataram, berdasarkan hasil perhitungan sistem (Rismayati dan Febri, 2019).

Permasalahan yang sering terjadi dalam bidang pendidikan adalah proses belajar mengajar dosen terhadap mahasiswa, penilaian proses belajar mengajar dosen masih dinomor dua kan atau ditiadakan dan penilaian melalui kasa mata, tanpa harus diberikan penilaian khusus terhadap yang bersangkutan. Hal ini justru menimbulkan masalah, yakni tidak dapat diketahui bagaimana progres proses belajar mengajar dosen terhadap mahasiswa. Metode Perbandingan Eksponensial dapat mengurangi bias yang mungkin terjadi dalam analisis, karena nilai skor yang dihasilkan mengambarkan urutan prioritas yang menjadi besar sehingga urutan prioritas alternatif keputusan menjadi lebih nyata (Kurdi, dkk, 2019).

\section{Metodologi Penelitian}

Penelitian yang dilakukan dapat dilihat pada pada gambar dan tabel berikut:

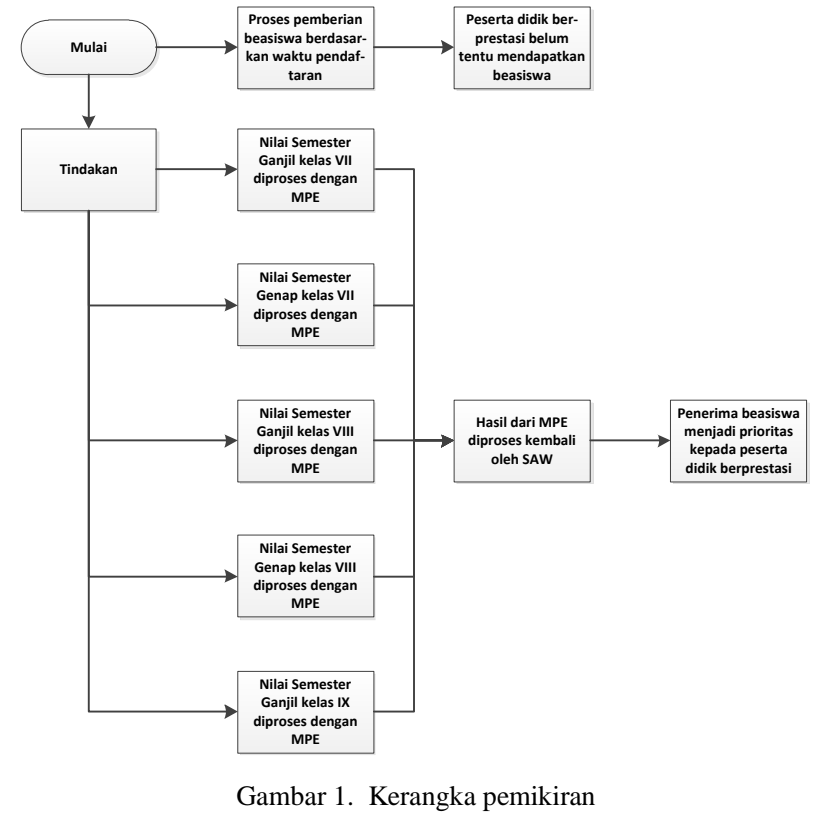

Proses yang diajukan adalah nilai peserta didik akan diproses rangking menggunakan Metode Perbandingan Eksponensial (MPE) disetiap akhir semesternya sesuai dengan kriteria dan bobot yang telah ditentukan. Setelah peserta didik mencapai akhir semester ganjil kelas IX, hasil rangking dari Metode Perbandingan Eksponensial (MPE) tersebut akan menjadi kriteria dengan bobot yang telah ditentukan untuk diproses oleh metode Simple Additive Weighting (SAW) guna mencapai hasil akhir yaitu peserta didik yang dapat menerima beasiswa di SMK Wiyata Mandala Bogor.

TABEL I

DATA PESERTA DIDIK SMP WIYATA MANDALA BOGOR

\begin{tabular}{clcc}
\hline No. & \multicolumn{1}{c}{ Peserta Didik } & Kelas & Jenis Kelamin \\
\hline 1 & Achmad Sofyan & IX-E & Laki - laki \\
\hline 2 & Adam Idris & IX-C & Laki - laki \\
\hline 3 & Ade Maesarotul Rizqoh & IX-C & Perempuan \\
\hline 4 & Ayu Sri Rahayu & IX-A & Perempuan \\
\hline 5 & Eka Gustiani & IX-E & Perempuan \\
\hline 6 & Erlangga Alfarizky & IX-F & Laki - laki \\
\hline 7 & Fefrianti Any & IX-E & Perempuan \\
\hline
\end{tabular}




\begin{tabular}{clcc}
\hline 8 & Fitri Fadila Ramah & IX-E & Perempuan \\
\hline 9 & Hariyansyah & IX-E & Laki - laki \\
\hline 10 & Ismi Marlia Sutisna & IX-D & Perempuan \\
\hline 11 & Khoirul Anwar & IX-D & Laki - laki \\
\hline 12 & Khoirunnisa & IX-F & Perempuan \\
\hline 13 & Maya Juliyanti & IX-A & Perempuan \\
\hline 14 & Peby Pebriani & IX-A & Perempuan \\
\hline 15 & Rendi & IX-F & Laki - laki \\
\hline 16 & Rodiah & IX-A & Perempuan \\
\hline 17 & Sindi Aldia & IX-A & Perempuan \\
\hline 18 & Sinta Silvia Dasa & IX-B & Perempuan \\
\hline 19 & Siti Zahara Chairunnisa & IX-C & Perempuan \\
\hline 20 & Sri Wahyuningsih & IX-A & Perempuan \\
\hline 21 & Susi Agustin & IX-F & Perempuan \\
\hline 22 & Yogi Saputra & IX-E & Laki - laki \\
\hline 23 & Zulfa & IX-B & Perempuan \\
\hline
\end{tabular}

Proses yang dilakukan sebelum menghitung penerima beasiswa adalah meencari rangking disetiap akhir semester berdasarkan kriteria yang telah ditentukan. Kriteria tersebut terdiri dari 5 kriteria mata pelajaran dan 5 kriteria prestasi yang pernah diraih oleh para peserta didik. Penentuan bobot telah disesuaikan berdasarkan tingkat kepentingan yaitu mata pelajaran Matematika dengan bobot awal 10 (sepuluh), namun bobot tersebut diperkecil menjadi 3 (tiga) dengan harapan hasil perhitungan dari Metode Perbandingan Eksponensial (MPE) tidak lebih dari angka 550 point.

TABEL II

BOBOT DAN KRITERIA METOdE PERBANDINGAN EKSPONENSIAL (MPE)

\begin{tabular}{lccc}
\hline \multicolumn{1}{c}{ Nama Kriteria } & Awal & Akhir & Kode \\
\hline Matematika & 10 & 3,00 & MTK \\
\hline Bahasa Indonesia & 9 & 2,85 & BID \\
\hline Bahasa Inggris & 8 & 2,70 & BIG \\
\hline Ilmu Pengetahuan Sosial (IPS) & 7 & 2,55 & IPS \\
\hline Teknologi Informasi dan Komunikasi & 6 & 2,40 & TIK \\
\hline Sertifikat lomba/Piagam penghargaan & 5 & 2,25 & SPH \\
\hline Organisasi/Ekstrakulikuler & 4 & 2,10 & EKS \\
\hline Absensi & 3 & 1,95 & ABS \\
\hline Pelanggaran Disiplin & 2 & 1,80 & PDS \\
\hline Usia Masuk SMP & 1 & 1,65 & UMS \\
\hline
\end{tabular}

Dari kriteria Metode Perbandingan Eksponensial (MPE) diatas, setiap kriteria memiliki tingkat range grade yang sudah ditentukan nilainya. Adapun untuk kriteria jenis pelajaran memiliki ketentuan angka nilai yang berlaku di SMP Wiyata Mandala Bogor yaitu 0 s/d 100 sehingga dalam angka dapat dilihat pada dibawah ini. Dalam proses penghitungan Metode Perbandingan Eksponensial (MPE), yang mana dalam proses perhitungannya menggunakan perkalian pangkat maka grade terendah adalah 1 (satu).

TABEL III

GRADE METode PeRbandingan EKSPONENSIAL (MPE)

\begin{tabular}{ccc}
\hline Nama Kriteria & Nilai & Angka \\
\hline \multirow{3}{*}{ Matematika } & $86-100$ & 5 \\
\cline { 2 - 3 } & 71 Sela -85 & 4 \\
\cline { 2 - 3 } & $56-70$ & 3 \\
\cline { 2 - 3 } & $41-55$ & 2 \\
\hline
\end{tabular}

\begin{tabular}{|c|c|c|}
\hline \multirow{5}{*}{ Bahasa Indonesia } & $86-100$ & 5 \\
\hline & $71-85$ & 4 \\
\hline & $56-70$ & 3 \\
\hline & $41-55$ & 2 \\
\hline & $0-40$ & 1 \\
\hline \multirow{5}{*}{ Bahasa Inggris } & $86-100$ & 5 \\
\hline & $71-85$ & 4 \\
\hline & $56-70$ & 3 \\
\hline & $41-55$ & 2 \\
\hline & $0-40$ & 1 \\
\hline \multirow{5}{*}{ Ilmu Pengetahuan Sosial (IPS) } & $86-100$ & 5 \\
\hline & $71-85$ & 4 \\
\hline & $56-70$ & 3 \\
\hline & $41-55$ & 2 \\
\hline & $0-40$ & 1 \\
\hline \multirow{4}{*}{$\begin{array}{l}\text { Teknologi Informasi dan } \\
\text { Komunikasi }\end{array}$} & $86-100$ & 5 \\
\hline & $71-85$ & 4 \\
\hline & $56-70$ & 3 \\
\hline & $41-55$ & 2 \\
\hline \multirow[t]{2}{*}{ Nama Kriteria } & Nilai & Angka \\
\hline & $0-40$ & 1 \\
\hline \multirow{2}{*}{$\begin{array}{l}\text { Sertifikat lomba/Piagam } \\
\text { penghargaan }\end{array}$} & Ada & 5 \\
\hline & Tidak & 1 \\
\hline \multirow[b]{2}{*}{ Organisasi/Ekstrakulikuler } & Ada & 5 \\
\hline & Tidak & 1 \\
\hline \multirow{2}{*}{ Absensi } & Rajin & 5 \\
\hline & Tidak & 1 \\
\hline \multirow{2}{*}{ Pelanggaran Disiplin } & Tidak & 5 \\
\hline & Ada & 1 \\
\hline \multirow{5}{*}{ Usia Masuk SMP } & 11 & 5 \\
\hline & 12 & 4 \\
\hline & 13 & 3 \\
\hline & 14 & 2 \\
\hline & 15 & 1 \\
\hline
\end{tabular}

Setelah proses Metode Perbandingan Eksponensial (MPE) disemester Ganjil kelas IX selesai, akan diproses kembali dengan Simple Additive Weighting (SAW) berdasarkan bobot dan kriteria seperti tabel berikut:

TABEL IV

BOBOT DAN KRITERIA SIMPLE ADDITIVE WEIGHTING (SAW)

\begin{tabular}{|c|c|c|c|}
\hline Semester & Alternatif MPE & Interval & Bobot \\
\hline \multirow{5}{*}{$\begin{array}{c}\text { Semester Ganjil } \\
\text { kelas VII }\end{array}$} & $424,533-530,665$ & 1,00 & \multirow{5}{*}{$10 \%$} \\
\hline & $344,933-424,532$ & 0,75 & \\
\hline & $291,867-344,932$ & 0,50 & \\
\hline & $265,333-291,866$ & 0,25 & \\
\hline & $0,000-265,332$ & 0,00 & \\
\hline \multirow{5}{*}{$\begin{array}{c}\text { Semester } \\
\text { Genap kelas } \\
\text { VII }\end{array}$} & $424,533-530,665$ & 1,00 & \multirow{5}{*}{$15 \%$} \\
\hline & $344,933-424,532$ & 0,75 & \\
\hline & $291,867-344,932$ & 0,50 & \\
\hline & $265,333-291,866$ & 0,25 & \\
\hline & $0,000-265,332$ & 0,00 & \\
\hline \multirow{5}{*}{$\begin{array}{c}\text { Semester Ganjil } \\
\text { kelas VIII }\end{array}$} & $424,533-530,665$ & 1,00 & \multirow{5}{*}{$20 \%$} \\
\hline & $344,933-424,532$ & 0,75 & \\
\hline & $291,867-344,932$ & 0,50 & \\
\hline & $265,333-291,866$ & 0,25 & \\
\hline & $0,000-265,332$ & 0,00 & \\
\hline \multirow{4}{*}{$\begin{array}{c}\text { Semester } \\
\text { Genap kelas } \\
\text { VII }\end{array}$} & $424,533-530,665$ & 1,00 & \multirow{4}{*}{$25 \%$} \\
\hline & $344,933-424,532$ & 0,75 & \\
\hline & $291,867-344,932$ & 0,50 & \\
\hline & $265,333-291,866$ & 0,25 & \\
\hline
\end{tabular}




\begin{tabular}{|c|c|c|c|}
\hline & $0,000-265,332$ & 0,00 & \\
\hline \multirow{5}{*}{$\begin{array}{l}\text { Semester Ganjil } \\
\text { kelas IX }\end{array}$} & $424,533-530,665$ & 1,00 & \multirow{5}{*}{$30 \%$} \\
\hline & $344,933-424,532$ & 0,75 & \\
\hline & $291,867-344,932$ & 0,50 & \\
\hline & $265,333-291,866$ & 0,25 & \\
\hline & $0,000-265,332$ & 0,00 & \\
\hline
\end{tabular}

\section{HASIL DAN PEMBAHASAN}

\section{A. Penerapan Metode Perbandingan Eksponensial (MPE)}

Pada tahap ini, data yang dihitung merupakan nilai peserta didik pada saat semester ganjil tahun pertama di SMP Wiyata Mandala Bogor.

TABEL V

DAFTAR NILAI MATA PELAJARAN PESERTA DIDIK

\begin{tabular}{lccccc}
\hline \multicolumn{1}{c}{ Nama } & MTK & BID & BIG & IPS & TIK \\
\hline Achmad Sofyan & 73 & 80 & 85 & 77 & 75 \\
\hline Adam Idris & 90 & 87 & 87 & 78 & 90 \\
\hline Ade Maesarotul Rizqoh & 78 & 82 & 78 & 87 & 70 \\
\hline \multicolumn{1}{c}{ Nama } & MTK & BID & BIG & IPS & TIK \\
\hline Ayu Sri Rahayu & 81 & 80 & 88 & 75 & 72 \\
\hline Eka Gustiani & 85 & 89 & 86 & 86 & 84 \\
\hline Erlangga Alfarizky & 89 & 88 & 71 & 70 & 74 \\
\hline Fefrianti Any & 76 & 71 & 76 & 89 & 86 \\
\hline Fitri Fadila Ramah & 87 & 86 & 70 & 70 & 89 \\
\hline Hariyansyah & 90 & 83 & 74 & 86 & 80 \\
\hline Ismi Marlia Sutisna & 70 & 81 & 82 & 88 & 70 \\
\hline Khoirul Anwar & 80 & 86 & 85 & 89 & 88 \\
\hline Khoirunnisa & 79 & 70 & 73 & 76 & 81 \\
\hline Maya Juliyanti & 72 & 90 & 84 & 70 & 70 \\
\hline Peby Pebriani & 88 & 70 & 75 & 71 & 79 \\
\hline Rendi & 83 & 70 & 87 & 88 & 82 \\
\hline Rodiah & 75 & 86 & 81 & 72 & 78 \\
\hline Sindi Aldia & 70 & 80 & 85 & 90 & 89 \\
\hline Sinta Silvia Dasa & 74 & 88 & 74 & 90 & 86 \\
\hline Siti Zahara Chairunnisa & 70 & 77 & 80 & 70 & 90 \\
\hline Sri Wahyuningsih & 73 & 87 & 73 & 84 & 70 \\
\hline Susi Agustin & 86 & 79 & 82 & 83 & 70 \\
\hline Yogi Saputra & 84 & 89 & 70 & 83 & 77 \\
\hline Zulfa & 77 & 90 & 79 & 87 & 73 \\
\hline
\end{tabular}

TABEL VI

DAFTAR NILAI PRESTASI PESERTA DIDIK

\begin{tabular}{lccccc}
\hline \multicolumn{1}{c}{ Nama } & SPH & EKS & ABS & PDS & UMS \\
\hline Achmad Sofyan & $\mathrm{T}$ & $\mathrm{T}$ & $\mathrm{R}$ & $\mathrm{T}$ & 12 \\
\hline Adam Idris & $\mathrm{T}$ & $\mathrm{A}$ & $\mathrm{T}$ & $\mathrm{T}$ & 14 \\
\hline Ade Maesarotul Rizqoh & $\mathrm{T}$ & $\mathrm{A}$ & $\mathrm{R}$ & $\mathrm{T}$ & 13 \\
\hline Ayu Sri Rahayu & $\mathrm{T}$ & $\mathrm{A}$ & $\mathrm{R}$ & $\mathrm{T}$ & 12 \\
\hline Eka Gustiani & $\mathrm{T}$ & $\mathrm{T}$ & $\mathrm{R}$ & $\mathrm{T}$ & 13 \\
\hline Erlangga Alfarizky & $\mathrm{T}$ & $\mathrm{A}$ & $\mathrm{R}$ & $\mathrm{T}$ & 12 \\
\hline Fefrianti Any & $\mathrm{A}$ & $\mathrm{A}$ & $\mathrm{R}$ & $\mathrm{T}$ & 13 \\
\hline Fitri Fadila Ramah & $\mathrm{T}$ & $\mathrm{A}$ & $\mathrm{R}$ & $\mathrm{T}$ & 13 \\
\hline Hariyansyah & $\mathrm{T}$ & $\mathrm{A}$ & $\mathrm{R}$ & $\mathrm{T}$ & 12 \\
\hline Ismi Marlia Sutisna & $\mathrm{T}$ & $\mathrm{A}$ & $\mathrm{R}$ & $\mathrm{T}$ & 12 \\
\hline Khoirul Anwar & $\mathrm{A}$ & $\mathrm{A}$ & $\mathrm{R}$ & $\mathrm{T}$ & 12 \\
\hline Khoirunnisa & $\mathrm{A}$ & $\mathrm{A}$ & $\mathrm{R}$ & $\mathrm{T}$ & 13 \\
\hline Maya Juliyanti & $\mathrm{T}$ & $\mathrm{A}$ & $\mathrm{R}$ & $\mathrm{T}$ & 13 \\
\hline Peby Pebriani & $\mathrm{T}$ & $\mathrm{T}$ & $\mathrm{R}$ & $\mathrm{T}$ & 12 \\
\hline Rendi & $\mathrm{T}$ & $\mathrm{A}$ & $\mathrm{R}$ & $\mathrm{A}$ & 12 \\
\hline
\end{tabular}

\begin{tabular}{llllll}
\hline Rodiah & T & A & R & T & 14 \\
\hline Sindi Aldia & A & A & T & T & 14 \\
\hline Sinta Silvia Dasa & T & A & R & T & 12 \\
\hline Siti Zahara Chairunnisa & T & T & R & T & 12 \\
\hline Sri Wahyuningsih & T & A & R & T & 14 \\
\hline Susi Agustin & T & A & R & T & 13 \\
\hline Yogi Saputra & T & A & R & T & 12 \\
\hline Zulfa & T & T & R & T & 13
\end{tabular}

TABEL VII

GRADE NILAI PRESTASI PESERTA DIDIK

\begin{tabular}{lccccc}
\hline \multicolumn{1}{c}{ Nama } & MTK & BID & BIG & IPS & TIK \\
\hline Achmad Sofyan & 4 & 4 & 4 & 4 & 4 \\
\hline Adam Idris & 5 & 5 & 5 & 4 & 5 \\
\hline Ade Maesarotul Rizqoh & 4 & 4 & 4 & 5 & 3 \\
\hline Ayu Sri Rahayu & 4 & 4 & 5 & 4 & 4 \\
\hline Eka Gustiani & 4 & 5 & 5 & 5 & 4 \\
\hline Erlangga Alfarizky & 5 & 5 & 4 & 3 & 4 \\
\hline Fefrianti Any & 4 & 4 & 4 & 5 & 5 \\
\hline Fitri Fadila Ramah & 5 & 5 & 3 & 3 & 5 \\
\hline Hariyansyah & 5 & 4 & 4 & 5 & 4 \\
\hline Ismi Marlia Sutisna & 3 & 4 & 4 & 5 & 3 \\
\hline Khoirul Anwar & 4 & 5 & 4 & 5 & 5 \\
\hline Khoirunnisa & 4 & 3 & 4 & 4 & 4 \\
\hline Maya Juliyanti & $\mathrm{T}$ & $\mathrm{A}$ & $\mathrm{R}$ & $\mathrm{T}$ & 13 \\
\hline & $\mathrm{SPH}$ & EKS & ABS & PDS & UMS \\
\hline Peby Pebriani & $\mathrm{T}$ & $\mathrm{T}$ & $\mathrm{R}$ & $\mathrm{T}$ & 12 \\
\hline Rendi & $\mathrm{T}$ & $\mathrm{A}$ & $\mathrm{R}$ & $\mathrm{A}$ & 12 \\
\hline Rodiah & $\mathrm{T}$ & $\mathrm{A}$ & $\mathrm{R}$ & $\mathrm{T}$ & 14 \\
\hline Sindi Aldia & $\mathrm{A}$ & $\mathrm{A}$ & $\mathrm{T}$ & $\mathrm{T}$ & 14 \\
\hline Sinta Silvia Dasa & $\mathrm{T}$ & $\mathrm{A}$ & $\mathrm{R}$ & $\mathrm{T}$ & 12 \\
\hline Siti Zahara Chairunnisa & $\mathrm{T}$ & $\mathrm{T}$ & $\mathrm{R}$ & $\mathrm{T}$ & 12 \\
\hline Sri Wahyuningsih & $\mathrm{T}$ & $\mathrm{A}$ & $\mathrm{R}$ & $\mathrm{T}$ & 14 \\
\hline Susi Agustin & $\mathrm{T}$ & $\mathrm{A}$ & $\mathrm{R}$ & $\mathrm{T}$ & 13 \\
\hline Yogi Saputra & $\mathrm{T}$ & $\mathrm{A}$ & $\mathrm{R}$ & $\mathrm{T}$ & 12 \\
\hline Zulfa & $\mathrm{T}$ & $\mathrm{T}$ & $\mathrm{R}$ & $\mathrm{T}$ & 13 \\
\hline & & & & &
\end{tabular}

TABEL VIII

GRADE NILAI PRESTASI PESERTA DIDIK

\begin{tabular}{lccccc}
\hline \multicolumn{1}{c}{ Nama } & SPH & EKS & ABS & PDS & UMS \\
\hline Achmad Sofyan & 1 & 1 & 5 & 5 & 4 \\
\hline Adam Idris & 1 & 5 & 1 & 5 & 2 \\
\hline Ade Maesarotul Rizqoh & 1 & 5 & 5 & 5 & 3 \\
\hline Ayu Sri Rahayu & 1 & 5 & 5 & 5 & 4 \\
\hline Eka Gustiani & 1 & 1 & 5 & 5 & 3 \\
\hline Erlangga Alfarizky & 1 & 5 & 5 & 5 & 4 \\
\hline Fefrianti Any & 5 & 5 & 5 & 5 & 3 \\
\hline Fitri Fadila Ramah & 1 & 5 & 5 & 5 & 3 \\
\hline Hariyansyah & 1 & 5 & 5 & 5 & 4 \\
\hline Ismi Marlia Sutisna & 1 & 5 & 5 & 5 & 4 \\
\hline Khoirul Anwar & 5 & 5 & 5 & 5 & 4 \\
\hline Khoirunnisa & 5 & 5 & 5 & 5 & 3 \\
\hline Maya Juliyanti & 1 & 5 & 5 & 5 & 3 \\
\hline Peby Pebriani & 1 & 1 & 5 & 5 & 4 \\
\hline Rendi & 1 & 5 & 5 & 1 & 4 \\
\hline Rodiah & 1 & 5 & 5 & 5 & 2 \\
\hline Sindi Aldia & 5 & 5 & 1 & 5 & 2 \\
\hline Sinta Silvia Dasa & 1 & 5 & 5 & 5 & 4 \\
\hline Siti Zahara Chairunnisa & 1 & 1 & 5 & 5 & 4 \\
\hline Sri Wahyuningsih & 1 & 5 & 5 & 5 & 2 \\
\hline Susi Agustin & 1 & 5 & 5 & 5 & 3 \\
\hline Yogi Saputra & 1 & 5 & 5 & 5 & 4 \\
\hline Zulfa & 1 & 1 & 5 & 5 & 3 \\
\hline & & & & &
\end{tabular}


Langkah berikutnya melakukan perhitungan untuk nilai semester ganjil kelas VII sesuai bobot kriteria yang telah ditentukan pada algoritma Metode Perbandingan Eksponensial (MPE) seperti berikut:

Achmad Sofyan : $\left(4^{\wedge} 3,00\right)+\left(4^{\wedge} 2,85\right)+\left(4^{\wedge} 2,70\right)+\left(4^{\wedge} 2,55\right)$ $+\left(4^{\wedge} 2,40\right)+\left(1^{\wedge} 2,25\right)+\left(1^{\wedge} 2,10\right)+\left(5^{\wedge} 1,95\right)+\left(5^{\wedge} 1,80\right)+$ $\left(4^{\wedge} 1,65\right)=273,398$

\section{B. Penerapan Simple Additive Weighting (SAW)}

Peserta didik yang sudah mencapai kelas IX dan menyelesaikan semester ganjil, maka point dari perhitungan Metode Perbandingan Eksponensial (MPE) semester ganjil kelas VII sampai dengan kelas IX semester ganjil sudah dapat diproses hitung dengan algoritma Simple Additive Weighting $(S A W)$. Langkah berikutnya adalah membuat tabel kecocokan dari hasil tersebut ke kriteria Simple Additive Weighting (SAW) yang telah ditentukan, sehingga akan menjadi seperti tabel berikut:

TABEL IX

KECOCOKAN ALTERNATIF TERHADAP KRITERIA

\begin{tabular}{lccccc}
\hline \multirow{2}{*}{ Nama } & \multicolumn{5}{c}{ Kelas \& Tingkat Semester } \\
\cline { 2 - 6 } & $\mathbf{7 - 1}$ & $\mathbf{7 - 2}$ & $\mathbf{8 - 1}$ & $\mathbf{8 - 2}$ & $\mathbf{9 - 1}$ \\
\hline Achmad Sofyan & 0,25 & 0,50 & 0,75 & 0,50 & 0,75 \\
\hline Adam Idris & 1,00 & 0,75 & 0,50 & 0,50 & 1,00 \\
\hline Ade Maesarotul Rizqoh & 0,50 & 0,75 & 0,50 & 0,75 & 0,50 \\
\hline Ayu Sri Rahayu & 0,50 & 0,75 & 0,75 & 1,00 & 0,75 \\
\hline Eka Gustiani & 0,75 & 0,50 & 0,00 & 0,75 & 0,75 \\
\hline Erlangga Alfarizky & 0,75 & 0,00 & 0,75 & 0,75 & 0,25 \\
\hline Fefrianti Any & 0,75 & 0,75 & 0,75 & 0,75 & 0,75 \\
\hline Fitri Fadila Ramah & 0,75 & 0,75 & 0,75 & 0,50 & 0,50 \\
\hline Hariyansyah & 0,75 & 0,50 & 0,50 & 1,00 & 0,50 \\
\hline Ismi Marlia Sutisna & 0,25 & 0,50 & 0,75 & 0,75 & 0,75 \\
\hline Khoirul Anwar & 1,00 & 0,75 & 0,50 & 0,75 & 0,75 \\
\hline Khoirunnisa & 0,50 & 0,50 & 0,00 & 1,00 & 0,50 \\
\hline Maya Juliyanti & 0,50 & 0,75 & 0,75 & 0,75 & 0,50 \\
\hline Peby Pebriani & 0,50 & 0,50 & 0,00 & 0,75 & 0,50 \\
\hline Rendi & 0,50 & 0,50 & 0,75 & 0,50 & 1,00 \\
\hline Rodiah & 0,50 & 0,75 & 0,25 & 0,75 & 0,50 \\
\hline Sindi Aldia & 0,50 & 0,50 & 0,25 & 0,25 & 0,75 \\
\hline Sinta Silvia Dasa & 0,75 & 1,00 & 0,25 & 0,25 & 0,25 \\
\hline Siti Zahara Chairunnisa & 0,00 & 0,50 & 0,25 & 0,00 & 0,75 \\
\hline Sri Wahyuningsih & 0,50 & 0,50 & 0,25 & 0,50 & 0,50 \\
\hline Susi Agustin & 0,75 & 0,75 & 0,25 & 1,00 & 0,50 \\
\hline Yogi Saputra & 0,50 & 0,75 & 0,50 & 0,50 & 0,25 \\
\hline Zulfa & 0,50 & 0,50 & 0,75 & 0,50 & 0,75 \\
\hline & & & & & \\
\hline & & & & \\
\hline
\end{tabular}

Proses berikutnya adalah melakukan normalisasi keputusan dengan cara menghitung nilai dari alternatif pada kriteria.

$r 11=0,25: M A X\{0,25 ; 1,00 ; 0,50 ; 0,50 ; 0,75 ; 0,75 ; 0,75$; 0,$75 ; 0,75 ; 0,25 ; 1,00 ; 0,50 ; 0,50 ; 0,50 ; 0,50 ; 0,50$; $0,50 ; 0,75 ; 0,00 ; 0,50 ; 0,75 ; 0,50 ; 0,50\}=0,25: 1,00=$ 0,25

$r 12=0,50: M A X\{0,50 ; 0,75 ; 0,75 ; 0,75 ; 0,50 ; 0,00 ; 0,75$; 0,$75 ; 0,50 ; 0,50 ; 0,75 ; 0,50 ; 0,75 ; 0,50 ; 0,50 ; 0,75$; $0,50 ; 1,00 ; 0,50 ; 0,50 ; 0,75 ; 0,75 ; 0,50\}=0,50: 1,00=$ 0,50 $r 13=0,75: M A X\{0,75 ; 0,50 ; 0,50 ; 0,75 ; 0,00 ; 0,75 ; 0,75$; 0,$75 ; 0,50 ; 0,75 ; 0,50 ; 0,00 ; 0,75 ; 0,00 ; 0,75 ; 0,25$; $0,25 ; 0,25 ; 0,25 ; 0,25 ; 0,25 ; 0,50 ; 0,75\}=0,75: 0,75=$ 1,00

$r 14=0,50: M A X\{0,50 ; 0,50 ; 0,75 ; 1,00 ; 0,75 ; 0,75 ; 0,75 ;$ 0,$50 ; 1,00 ; 0,75 ; 0,75 ; 1,00 ; 0,75 ; 0,75 ; 0,50 ; 0,75$; $0,25 ; 0,25 ; 0,00 ; 0,50 ; 1,00 ; 0,50 ; 0,50\}=0,50: 1,00=$ 0,50

r15 = 0,75: $\mathbf{M A X}\{0,75 ; 1,00 ; 0,50 ; 0,75 ; 0,75 ; 0,25 ; 0,75$; 0,$50 ; 0,50 ; 0,75 ; 0,75 ; 0,50 ; 0,50 ; 0,50 ; 1,00 ; 0,50$; $0,75 ; 0,25 ; 0,75 ; 0,50 ; 0,50 ; 0,25 ; 0,75\}=0,75: 1,00=$ 0,75

Hasil dari peringkat kinerja ternormalisasi dalam bentuk matriks dapat dilihat pada gambar berikut:

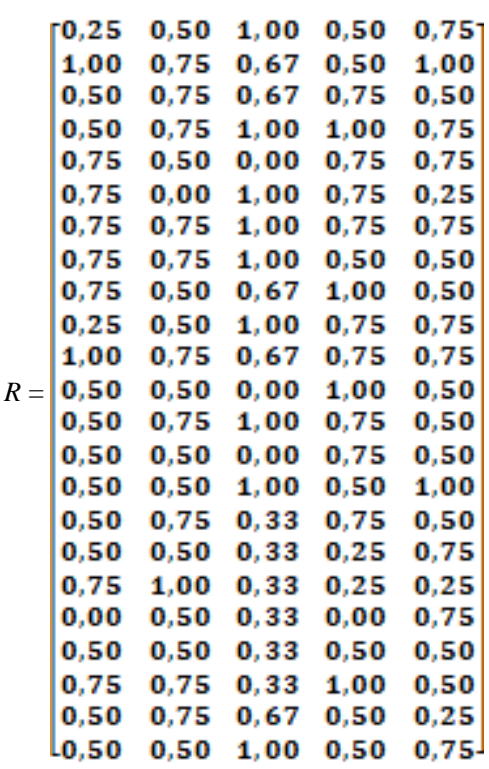

Gambar 2. Matriks ternormalisasi

Proses berikutnya adalah menghitung hasil akhir preferensi yang diperoleh dari penjumlahan dari perkalian elemen baris matriks ternormalisasi dengan bobot kriteria yang telah ditentukan pada algoritma Simple Additive Weighting (SAW) yang bersesuaian dengan elemen kolom matriks seperti berikut:

Achmad Sofyan : $(0,25 * 0,10)+(0,50 * 0,15)+(1,00 * 0,20)+$ $(0,50 * 0,25)+(0,75 * 0,30)=0,6500$

Hasil perhitungan akhir dari masing-masing peserta didik apabila diurutkan dari nilai tertinggi sampai dengan nilai terendah dapat dilihat pada tabel berikut:

TABEL X

RANGKING PENERIMA BEASISWA

\begin{tabular}{lccc}
\hline \multicolumn{1}{c}{ Nama } & Kelas & Jenis Kelamin & Skor \\
\hline Ayu Sri Rahayu & IX-A & Perempuan & 0,8375 \\
\hline Fefrianti Any & IX-E & Perempuan & 0,8000 \\
\hline Adam Idris & IX-C & Laki - laki & 0,7715 \\
\hline
\end{tabular}




\begin{tabular}{lccc}
\hline Khoirul Anwar & IX-D & Laki - laki & 0,7590 \\
\hline Rendi & IX-F & Laki - laki & 0,7500 \\
\hline Ismi Marlia Sutisna & IX-D & Perempuan & 0,7125 \\
\hline Maya Juliyanti & IX-A & Perempuan & 0,7000 \\
\hline Hariyansyah & IX-E & Laki - laki & 0,6840 \\
\hline Zulfa & IX-B & Perempuan & 0,6750 \\
\hline Fitri Fadila Ramah & IX-E & Perempuan & 0,6625 \\
\hline Susi Agustin & IX-F & Perempuan & 0,6535 \\
\hline Achmad Sofyan & IX-E & Laki - laki & 0,6500 \\
\hline Ade Maesarotul Rizqoh & IX-C & Perempuan & 0,6340 \\
\hline Rodiah & IX-A & Perempuan & 0,5660 \\
\hline Eka Gustiani & IX-E & Perempuan & 0,5625 \\
\hline Erlangga Alfarizky & IX-F & Laki - laki & 0,5375 \\
\hline Khoirunnisa & IX-F & Perempuan & 0,5250 \\
\hline Yogi Saputra & IX-E & Laki - laki & 0,4965 \\
\hline Sindi Aldia & IX-A & Perempuan & 0,4785 \\
\hline Sri Wahyuning-sih & IX-A & Perempuan & 0,4660 \\
\hline Peby Pebriani & IX-A & Perempuan & 0,4625 \\
\hline \multicolumn{1}{c}{ Nama } & Kelas & Jenis Kelamin & Skor \\
\hline Sinta Silvia Dasa & IX-B & Perempuan & 0,4285 \\
\hline Siti Zahara Chairunnisa & IX-C & Perempuan & 0,3660 \\
\hline
\end{tabular}

\section{KESIMPULAN}

Penerapan Metode Perbandingan Eksponensial (MPE) dan Simple Additive Weighting (SAW) dapat membantu dan mengoptimalkan penyaluran beasiswa berprestasi kepada peserta didik di SMP Wiyata Mandala Bogor.

Rangking yang dihasilkan pada penelitian ini dapat memenuhi kebutuhan Yayasan Pradnya Paramarta dalam mencapai tujuannya yaitu mencetak lulusan yang kompeten, dimana proses yang dilakukan pada sistem ini berdasarkan nilai dan prestasi peserta didik selama berada ditingkat kelas VII, VIII dan IX semester ganjil.

\section{UCAPAN TERIMA KASIH}

Terima kasih kami ucapkan kepada semua pihak-pihak yang turut membantu perancangan sistem ini yaitu keluarga besar, dosen, sahabat-sahabat serta lainnya yang tidak bisa kami sebutkan satu persatu. Kami mengucapkan terima kasih atas bantuannya baik yang materiel maupun immaterial.

\section{REFERENSI}

[1] Abdulloh, Rohi. "Web Programing is Easy." PT. Elex Media Komputindo. Jakarta. 2015.

[2] Alatas, Husein. "Responsive Web Design dengan PHP dan Bootstrap." Lokomedia. Yogyakarta. 2013.

[3] Hidayat, Rachmat. (2017). Metode Simple Additive Weighting Sebagai Sistem Pendukung Keputusan Penerima Beasiswa Murid Berprestasi. Jurnal \& Penelitian Teknik Informatika. Vol. 2 Edisi 2, 13-17.

[4] Kadir, A. "Konsep dan Tuntunan Praktis Basis Data." Andi. Yogyakarta. 1999.

[5] Kurdi, Anton, dkk. (2019). Penerapan Metode Perbandingan Eksponensial Pada Penilaian Proses Belajar Mengajar di Fakultas Teknik Universitas Muhammadiyah Bengkulu. Jurnal Informatika UPGRIS. Vol. 5 Edisi 2, 182-187.

[6] Pratiwi, Heny. "Buku Ajar Sistem Pendukung Keputusan." Deepublish. Yogyakarta. 2016.

[7] Rismayati, Ria dan Febri Mamluatul Ulumi. (2019). Implementasi Metode Perbandingan Eksponensial (MPE) Dalam Pendukung
Keputusan Penilaian Kepala Madrasah Terbaik Di Kota Mataram. Jurnal Teknologi Informasi dan Multimedia. Vol. 1 Edisi 3, 188-197.

[8] Rosa, Ariani Sukamto dan Shalahuddin "M. Rekayasa Perangkat Lunak Terstruktur dan Berorientasi Objek". Informatika. Bandung. 2014

[9] Saputra, Agus. "Trik dan Solusi Jitu Pemrograman PHP." PT. Elex Media Komputindo. Jakarta. 2011.

[10] Simarmata, Janer. "Perancangan Basis Data.” Andi. Yogyakarta. 2010.

[11] Widodo, B dan Suhartono Derwin. "Artificial Intelligence Konsep dan Penerapannya.” Andi. Yogyakarta. 2014. 